\title{
THE EXPLOITATION OF THE ESTUARIES IN THE KENDAL AREA (NORTHERN COAST OF JAWA) BY ARTISANAL FISHERMEN ${ }^{1)}$
}

\author{
by
}

\author{
HARJADI HADIKOESWORO ${ }^{2}$ )
}

\begin{abstract}
The estuaries at the northern coast of Jawa are good fishing grounds for the artisanal fishermen. They have been exploited heavily, and is becoming more so with the advance of technology in the form of motorized vessels. Does the exploitation provide a good livelihood to the fishermen? The outcome of the preliminary analysis of the fishing activities of artisanal fishermen in the Kendal area (Central Jawa) will be presented, the problems discussed.
\end{abstract}

\section{INTRODUCTION}

The estuaries of the Northern coast of Java is considered to be one of the most productive fishing grounds in Indonesia. Many rivers discharge their water rich in nutrients to Jawa Sea, which supports an abundant fish population. The fish population in turn support the life of the artisanal fishermen living in the coastal villages.

The fishing operation remains backward utilizing antiquated gears and sailboats able to venture not more than 10 miles to the sea. Now they are living below subsistent standard, and facing an ever declining prosperity. With the population increase more and more boats are participating in the catch, reducing the amount of catch per boat and hence their income too. With the advance of technology in the form of motorized boat equipped with more efficient purse seine or trawl, not only the mere existence of the fishing community is jeopardized but also the fish stock in declining so that the sustainable catch is lower than before.

This is a case of a conservation problem in which at least there is a close relationship between two groups, one is the fish population and the other is the fishermen exploiting the stock. A change of population of one of the group will affect the other population, and the advance of new technology

1) This contribution has arisen as an excerpt of the result of the Ecology Project on coastal Villages in the Kendal area financed by Survey Agro Ekonomi Indonesia and A/D/C. The author is grateful to both agencies for the use of the data partially collected so far.

2) Senior Lecturer at the Department of Socio-and Economics of Agriculture, Bogor Agricultural University (IPB), research member of the Ecology Project. 


\section{HARJADI HADIKOESWORO}

affects both. In a developing country the urge to produce more is inevitable and is to be encouraged, but the consequences of the effort to the communities should be weighed with great care.

\section{THE EXPLOITATION}

In the two villages in our study area namely Rowosari and Bandengan in Kabupaten Kendal, Central Jawa, artisanal fisherman use sailboats only. They can be categorized into two classes, the small boats with a crew of two to six and the medium sized boats with a crew of ten to sixteen. They depend mostly on existing wind for propulsion so that the range of the trip and the duration of fishing operation is limited.

Most of the fishermen use gillnets of all kinds of mesh. The small mesh to catch shrimp, mostly Penaeus merguiensis, 'teri' (Stolephorus spp.), 'petek' (Leiognathus spp.) etc. The medium mesh for 'selar' (Caranx spp.), 'tembang' (Clupea spp.), 'kembung' (Rastrelliger spp), 'layang' (Decapterus spp.) etc. The big meshed gillnet is used to catch tuna (Thunnus spp.), mackerel (e.g. Scomberomorus spp.), pompano (Pompus spp.), 'tiga waja' (Sciaena spp., Pseudosciaena spp.) etc. The 'payang' or 'jabur' i.e. a midwater trawl is used to catch cutlassfish (Trichiurus spp.) and miscellanous fish. Dipnet is used to catch jelly fish and squids. Hook and line is employed to catch bigger fish like seabass or 'kakap' (Lates calcarifer), seacatfish like the 'munyung' (Arius thalassinus), red snapper (Lutjanus sp.) and others.

As is true for all artisanal fishermen, their livelihood depends basically on the season. The season determines the waterquality, and current which in turn determines the migration offish and availability which then determines the kind of gear used. The season furthermore characterized the wind and wave which determine the duration and the range of operation and whether the fishermen want or don't want to go.

In the Kendal area there are four seasons, the characteristics of those are as follows.

1. 'Musim Kanem' or 'Musim Angin Barat' or the Easterly wind season, from December to February. High waves and rain. Considered to be a season of lean catch.

2. 'Musim Kawolu', from March to May, calm weather, South Easterly wind in the morning, Easterly wind in the afternoon, Good season.

3. 'Musim Peteruh', from June to August, same wind as 'Musim Kawolu', small waves. Lean catch.

4. 'Musim Kapat', from September to November. Westerly wind with occasional Northeasterly wind, rather high waves. Good season. 


\section{THE EXPLOITATION OF THE ESTUARIES}

\section{THE DECREASING INCOME}

The income of the fishermen vary with the season. A good season will produce high income, but the variation of income between seasons is not as great as the variation of catch, because during the season of plenty the price of fish invariably falls down. On the other hand during a meager season the price of fish increases a little bit resulting in a less pronounced variation of income between seasons. However it is always true that a good season gives higher income to the fishermen than the off-season period.

In the village Rowosari the seasonal variation of monthly income is clearly shown in the following table.

TABLE 1. Gross income per month, return per hour labour. Boat owners and Fishing Labourers, Rowosari. US \$

$\begin{array}{llllll}\text { Oct. } & \text { Nov. } & \text { Dec. } & \text { Jan. } & \text { Feb. } & \text { March } \\ 75 & 75 & 75 & 76 & 76 & 76\end{array}$

Boat owners

Gross income/

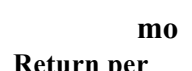

20.22

26.19

16.37

8.59

35.63

45.19

hour labour

0.09

0.10

0.08

0.06

0.11

0.19

Fishing labourers

Gross income/

Return per

8.10

6.14

3.77

4.31

9.03

8.52

hour labour

0.03

0.02

0.02

0.03

0.03

0.03

Source : data from the Survey on Ecology of coastal Villages. S.A.E./A/D/C, unpublished.

As shown in the table the income is high in October and November, and lowest in December and January to increase again in March i.e. beginning of the 'musim kawolu'. The return per hour labour in the part of the boat owners is lowest in December and January as a consequence of the high waves and wind prevailing in the season whereby the number of success i.e. 


\section{HARJADI HADIKOESWORO}

the boat trip in which some fish is caught, is low in comparison with the total trip.

The table suffices us to know that their income is low. The real decrease of income from year to year cannot be shown here. To make ends meet other members of the fishermen's family do seek jobs outside fishery to earn additional income, but it never amounts higher than $39 \%$ of the total income.

Very remarkable is the earnings received from sales or pawning of household assets and loans. In October the sales of assets and pawning is only $10 \%$ of the total income, and the loan received is up to $12 \%$. But in January the sales of assets and pawning increased to $15 \%$ whereas the loan received is up to $29 \%$.

\section{THE DECREASING CATCH}

According to the fishermen, beginning about 2 years ago the catch began to decrease and so far never increased again. Unseasonally low catch occurs throughout the year. Each year they make offering to 'Nyai Loro Kidul', who is believed to be the goddess of the sea, on a day of celebration called 'nyadran'. In the past, the offerings will soon pay off in the form of abundant catch. But in 1975 and 1976, immediately after the offering ceremony the catch was very meager. Many people believe at first that the season in changing. After the westerly wind season they expected that the catch would increase again. However, because of the belief that the season changes, they could tolerate a little delay. But the abundant catch never happened again and they live miserably ever since.

We may suspect that this adverse condition is a result of the declining fish population. May be it is the result of over fishing, leading to a lowering of the biomass and the sustainable catch. Indeed the number of crafts is increasing in the last seven years. In Bandengan there were 56 medium sized boats and 69 small boats in 1969, and in 1973 there were respectively 52 and 240. The number of crafts alone may explain the overfishing, let alone the increase of number of trips that might be undertaken.

The condition is still further worsened by the fact that more and more motorized boats are participating in the catch in the Kendal estuaries fishing grounds. They are efficient catchers coming from Semarang, Pekalongan, Batang, Cirebon and occasionally even from Bagan Si Api-api in Sumatra.

Many people confide that the use of a net with smallmesh can catch not only small fish but juveniles as well. This net has been used by artisanal 


\section{THE EXPLOITATION OF THE ESTUARIES}

fishermen for a long time apparently with no ill effect, but when the more efficient motorized boat are using this kind of net too, more juveniles are caught, and the continuous catch may lower the fish population in the future.

We may think also that the increasing use of pesticides in agriculture may have bad consequences to the fish population, but nobody has proven it for the Kendal estuaries.

\section{COMPETITION WITH MOTORIZED BOATS}

The presence of motorized boats in the Kendal area fishing grounds generates friction with the local fishermen. They are utilizing a purse-seine or an otter trawl which can catch fish in large quantities in shorter time. Their freezer holds can store fish for a few days so that their operation may last for several days at a stretch if shoals of migrating fish or resident species are discovered. Not only they are accused of taking fish from their fishing grounds but also because their reckless way of operation has damaged the traditional fishermen's gears.

A regulation was passed by the Central Jawa Province in which a sole right was given to the traditional fishermen to catch fish up to 10 miles from the shore. The seemingly good solution is deemed worthless by the local fishermen since there is a difficulty of enforcement. Motivated by higher income when high priced shrimp is caught by the artisanal fishermen, the motorized boats will converge in the 10 mile strip disregarding the regulation. In this clandestine operation the trawlers and purse seiners use no lights so that sometimes sailboats are run down and nets are entangled and torn.

In a way the change from sailboats to motorized vessels is to be desired if we endeavour to develop the traditional fishery. But the growing pains of the fledgeling industrial fishery put too much pressure to the traditional fishermen, especially when the motorized boat are not adopted by the local fishermen. This transitional period creates two competing groups facing each other with different views about fishery. The new group is profit oriented and operates commercially, whereas the old group is subsistent oriented and operates in the traditional sharing system to live in harmony in a community with intricate custom that seemingly defies any effort to change. Of course in the course of development we cannot sacrifice the whole multitude of traditional fishing community for the sake to give profit to several enterpreneurs. 


\section{HARJADI HADIKOESWORO}

Finally in a situation where the two groups coexist in utilizing a common property resource trying to secure their very existence a balance of nature is at stake. The delicate balance of resource use might be tipped and the whole community offish and fishermen might colapse.

\section{RECOMMENDATION}

As a sound basis for fishery exploitation the fish stock should be known before trying to augment fishery production. Therefore a research to estimate the biomass of fish is of prime importance and should be undertaken in the near future.

In the effort to modernize the fishing operation great care should be taken that any measure to develop industrial fishery should not jeopardize the traditional fishermen.

Research to discover new fishing grounds and to determine under utilized fishing grounds might be important to relocate existing motorized vessels which compete with the artisanal fishery operation.

Transmigrating fishermen to new or under-utilized fishing grounds could be planned if it is socially acceptable and economically feasible.

Regulation controlling the exploitation of the sea is needed to improve the standard of living of the fishermen and to maintain an optimum biomass and a high sustained yield.

If limitation of entry is necessary a longrun plan to relocate fishermen to other fishing grounds or training the next generation to acquire skills other than fishing is necessary. 